\title{
SAFETY ASSESSMENT OF TOCOTRIENOL SUPPLEMENTATION IN SUBJECTS WITH METABOLIC SYNDROME: A RANDOMISED CONTROL TRIAL
}

GAN YEE LIN*; LAI OI MING*; CHEW BOON HOW**; YUEN KAH HAY; ${ }^{\star *}$ KALANITHI NESARETNAM ${ }^{\ddagger}$; TENG KIM-TIU ${ }^{\ddagger \ddagger}$; KANGA RANI SELVADURAY ${ }^{\ddagger \ddagger}$; PUVANESWARI MEGANATHAN ${ }^{\ddagger \ddagger}$ and FU JU YEN ${ }^{\ddagger \ddagger}$

\begin{abstract}
Previous studies have reported that tocotrienols (T3) possess many distinct properties such as antioxidant, cardioprotective, neuroprotective, anti-cancer, anti-inflammatory and anti-angiogenic, which are beneficial for the improvement of human health. However, there is limited data available on the safety assessment of T3 compared to tocopherols (T). A randomised, double-blinded, cross-over and placebo-controlled human clinical trial was conducted to determine the safety and tolerance of T3 supplementation in 31 subjects with metabolic syndrome. The subjects were supplemented with tocotrienol-rich fraction (TRF) $200 \mathrm{mg}$ or placebo capsules twice daily for two weeks followed by a post-intervention visit. Results showed that T3 supplementation had no significant adverse effect on the red blood cell (RBC), white blood cell (WBC) and platelet counts between TRF $\left(5.10 \pm 0.78 \times 10^{12}\right.$ litre $^{-1}, 7.35 \pm 1.59 \times 10^{9}$ litre $^{-1}, 279.45 \pm 73.86 \times 10^{9}$ litre $^{-1}$, respectively) and placebo interventions (5.13 $\pm 0.76 \times 10^{12}$ litre $^{-1}, 7.25 \pm 1.95 \times 10^{9}$ litre $^{-1}, 267.45$ $\pm 68.72 \times 10^{9}$ litre $^{-1}$, respectively). Measures of serum aspartate aminotransferase (AST), serum alanine aminotransferase $(A L T))$ and albumin did not differ between TRF (25.68 $\pm 10.72 \mathrm{IU}_{\text {litre }}{ }^{-1}, 38.26 \pm 24.74$ IU litre ${ }^{-1}, 43.61 \pm 2.26 \mathrm{~g}$ litre $^{-1}$, respectively) and placebo interventions (27.39 $\pm 16.44 \mathrm{IU}_{\text {litre }}{ }^{-1}, 42.23 \pm$ 33.58 IU litre ${ }^{-1}, 43.68 \pm 2.15 \mathrm{~g} \mathrm{litre}^{-1}$, respectively).This study indicated that supplementation with T3 at the dosage of $400 \mathrm{mg}$ per day for 14 days did not induce haematoxicity and hepatotoxicity in subjects with metabolic syndrome.
\end{abstract}

Keywords: tocotrienol, vitamin E, metabolic syndrome, safety.

Date received: 27 January 2014; Sent for revision: 3 July 2014; Received in final form: 18 September 2015; Accepted: 20 November 2015.

\footnotetext{
* Department of Bioprocess Technology, Faculty of Biotechnology and Biomolecular Sciences, Universiti Putra Malaysia, 43400 UPM Serdang, Selangor, Malaysia.

** Department of Family Medicine, Faculty of Medicine and Health Sciences, Universiti Putra Malaysia,

43400 UPM Serdang, Selangor, Malaysia.
}

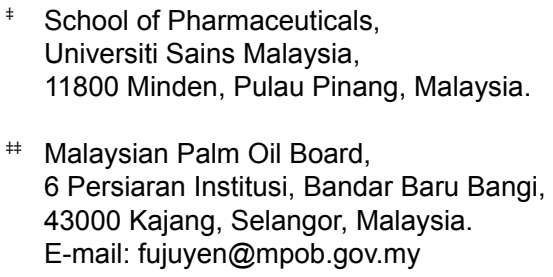




\section{INTRODUCTION}

Tocotrienols (T3) is one group of fat soluble vitamin $\mathrm{E}$ apart from tocopherols (T). It was discovered in 1964, i.e. about 40 years later than T, by Pennock and Whittle (Pennock et al., 1964). Since then, vitamin E was recognised as a family of compounds consisting of two groups known as $\mathrm{T}$ and T3. The molecular structure of $\mathrm{T}$ comprises a chromanol ring and saturated isopretyl side chain, whereas T3 have an addition of three double bonds in the side chain. There are four members in each group, i.e. alpha $(\alpha-)$, beta $(\beta-)$, gamma $(\gamma-)$ and delta $(\delta-)$, named according to the number and position of methyl groups attached to the chromanol ring (Schauss et al., 2012). Numerous studies showed that T3 possess many unique functions such as neuroprotective (Khanna et al., 2005), cholesterol lowering (Qureshi et al., 1997), anti-hypertensive (Newaz and Nawal, 1999), immunomodulatory (Mahalingam et al., 2011), and cardioprotective (Schauss et al., 2012), which are beneficial to different health conditions such as cancer, type 2 diabetes mellitus and stroke.

The prevalence of individuals with metabolic syndrome is increasing. These individuals are diagnosed with a cluster of risks factors including abdominal obesity, atherogenic dyslipidemia, elevated blood pressure, insulin resistance, proinflammatory and pro-thrombotic states (Grundy et al., 2005). They have an increased risk of developing cardiovascular diseases and type 2 diabetes mellitus. Obesity is an independent risk factor associated with higher cardiovascular disease risk. Excessive adiposity in individuals with metabolic syndrome promotes the release of pro-inflammatory cytokines, non-esterified fatty acids and free fatty acids, which then lead to insulin resistance, vascular dysfunction, artherogenic dyslipidemia, and atherosclerosis (Haffner, 2006; Huang, 2009). Insulin resistance is often related to atherogenic dyslipidemia, which causes reduced serum level of high density lipoprotein cholesterol (HDL-C) and elevated serum triacylglycerol (TAG). In addition, activation of renin angiotensin system in the excessive adipose tissue leads to hypertension (Huang, 2009). Thus, it is known that most components in metabolic syndrome are interrelated and share common pathway mediators. The T3 have previously been demonstrated to reduce blood glucose (Budin et al., 2009), blood pressure (Newaz and Nawal, 1999), TAG (Zaiden et al., 2010) and body fat (ImaNirwana and Suhaniza, 2004). In fact, several studies in hypercholesterolemic subjects reported a reduction in total cholesterol and LDL-cholesterol after supplementation of tocotrienol-rich fraction (TRF) up to $300 \mathrm{mg}$ (Qureshi et al., 1991; Yuen et al., 2012). Therefore, it has the potential to act as a multitargeted therapy to manage metabolic syndrome and the risk of developing cardiovascular disease.
However, several studies found that high doses (400 IU) of vitamin E could cause an increase in adverse event compared to placebo control group (Lonn et al., 2005; Klein et al., 2011). These findings were further concurred by two meta-analysis conducted by Miller et al. (2005) and Bjelakovic et al. (2007), which indicated that high dosage of vitamin $\mathrm{E}$ increase all-cause mortality. A recent Cochrane systematic review done by Bjelakovic et al. (2012) also concurred with the finding that vitamin $\mathrm{E}$ has the tendency to increase all-cause mortality. They suggested that the increase in all-cause mortality may be due to the increased incidence in cancer and cardiovascular mortality. However, in the studies mentioned above, subjects were not supplemented with $\mathrm{T} 3$ but $\mathrm{T}$, both natural and synthetic forms. In view of the absence of T3 in the above studies, the conclusions could not be applicable to T3. An animal study conducted by Oo et al. (1992) reported that the administration of T3 dosage up to $2500 \mathrm{mg} \mathrm{kg}^{-1}$ body weight did not induce any adverse effect in the animals tested. However, there is insufficient documentation and clinical studies reporting the safety evaluation of T3 supplementation in human subjects, especially on the haematological and hepatological profiles. Therefore, this study aimed to investigate the safety and tolerance of T3 supplementation at $400 \mathrm{mg}$ per day for two weeks by measuring haematological and liver function markers as well as by recording observations of undesirable events.

\section{Study Design}

\section{EXPERIMENTAL}

This was a randomised, double-blind, crossover and placebo-controlled trial consisting of two interventions as shown in Figure 1. Subjects were randomly assigned to start with any of the two interventions. Each intervention involved two weeks of supplementation with two weeks of washout period in between. As the absorption of vitamin $\mathrm{E}$ may vary according to the daily fat intake of the subjects, packets of $125 \mathrm{ml}$ full cream milk (each containing $4.3 \mathrm{~g}$ of fat) were given to subjects in order to ensure they have standardised intake of fat for T3 absorption and to minimise the inter-individual differences or responses across the intervention. Subjects consumed one capsule together with 125 $\mathrm{ml}$ full cream milk after breakfast and one capsule together with $125 \mathrm{ml}$ full cream milk after dinner. Blood samples were collected on Day 0 and Day 14 of the study. Throughout the study period, subjects maintained their usual lifestyle and diet. A dietary guideline and a five-day diet diary was provided. Subjects were requested to record the descriptions of all foods and beverages taken for two weekdays, one weekend day and the dinner prior to postprandial visits. The individual dietary data for the dinner 


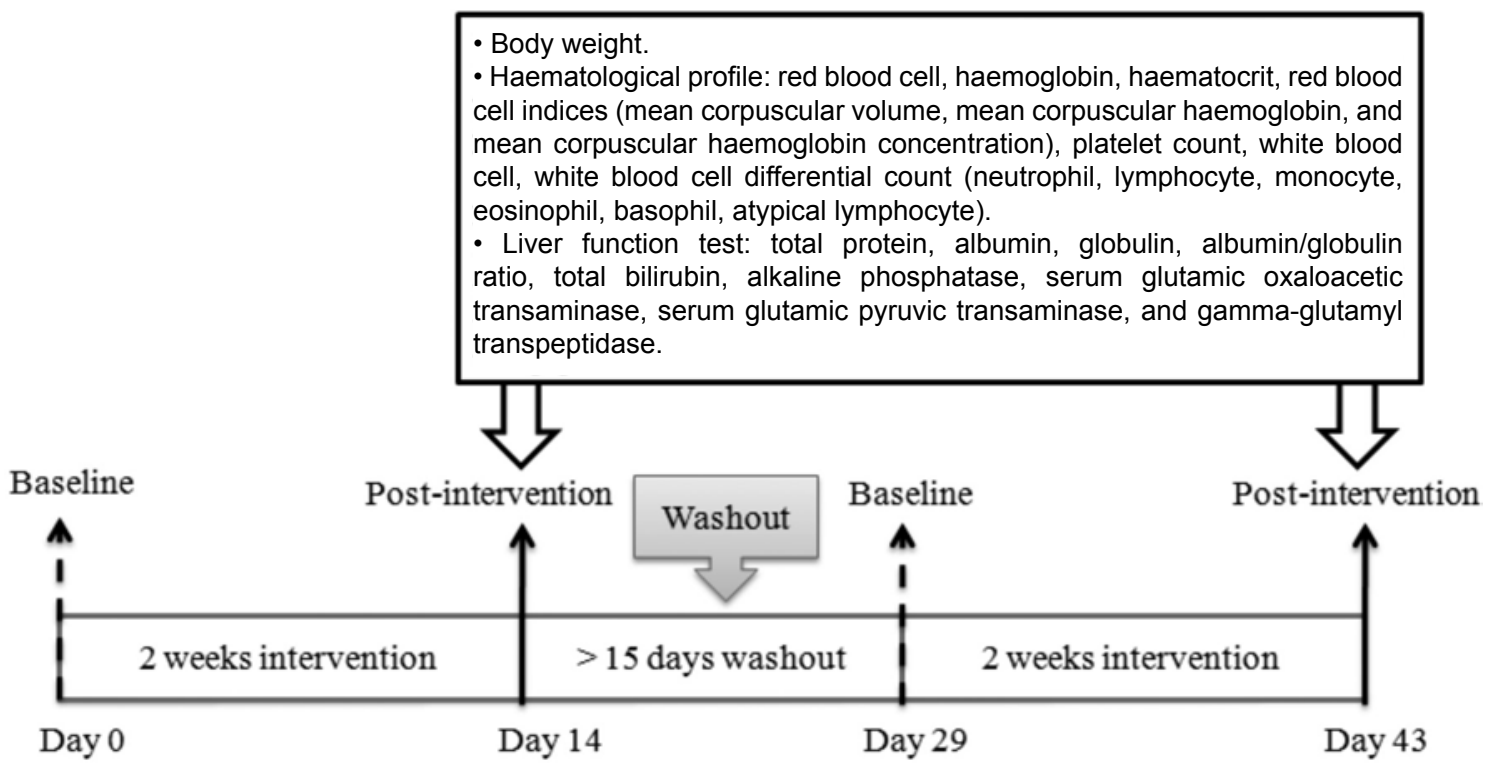

Figure 1. Study design.

prior to the postprandial visit was then analysed using Nutritionist Pro software (Version 4.6, Axxya Systems, LLC, USA) to estimate the energy intake. Any usage of medications that interfere with the results of this study was not allowed. However, if medication is critical and important for the subjects' health, it was sanctioned and considered as dropout. The experimental protocol was approved by the Medical Research Ethics Committee of Universiti Putra Malaysia and registered in ClinicalTrials.gov (NCT01631838).

\section{Intervention}

Two interventions involved in this trial were TRF and placebo. In TRF group, subjects were supplemented with Tocovid ${ }^{\mathrm{TM}}$ SupraBio $^{\mathrm{TM}} 200 \mathrm{mg}$. Each capsule is comprised of $61.52 \mathrm{mg} \mathrm{d}-\alpha-\mathrm{T} 3,112.8$ mg d- $\gamma-\mathrm{T} 3,25.68 \mathrm{mg}$ d- $\delta-\mathrm{T} 3,91.6 \mathrm{IU} \mathrm{d}-\alpha-\mathrm{T}$ (200 mg of T3 and $61.07 \mathrm{mg} \mathrm{d}-\alpha-\mathrm{T})$. On the other hand, the placebo capsule consisted of palm olein with the amount of T3 less than $1 \mathrm{mg}$. Both supplements were obtained from Hovid Bhd (Perak, Malaysia) and they have identical physical appearance.

\section{Subjects}

In this study, 32 subjects ( $\mathrm{n}=16$ males and $\mathrm{n}=16$ females) were sampled from adults population with age category ranging from $25-56$ years in Malaysia. Metabolic syndrome was identified according to the local Clinical Practice Guidelines, Management of Type 2 Diabetes Mellitus in Malaysia (2009), with waist circumference more than $90 \mathrm{~cm}$ in men and 80 $\mathrm{cm}$ in women, and any two of the following criteria: elevated fasting TAG level $\left(\geq 1.69 \mathrm{mmol}\right.$ litre $\left.^{-1}\right)$, fasting level of HDL-C of less than $1.0 \mathrm{mmol}^{\text {litre }}{ }^{-1}$ in men and $1.3 \mathrm{mmol}$ litre $^{-1}$ in women, elevated blood pressure $(\geq 130 / \geq 85 \mathrm{~mm} \mathrm{Hg})$ or fasting glucose level between $5.6 \mathrm{mmol}_{\text {litre }}{ }^{-1}$ to $7 \mathrm{mmol}$ litre $^{-1}$.

Subjects were not recruited if the fasting haemoglobin $(\mathrm{Hb})$ level falls below $11.5 \mathrm{~g} \mathrm{dl}^{-1}$ in women and $12.5 \mathrm{~g} \mathrm{dl}^{-1}$ in men, and if the serum ferritin level is less than $15 \mu \mathrm{g}$ litre $^{-1}$. The subjects were excluded if they had any medical history of myocardial infarction, angina, ischemic attack, haemorrhagic stroke, deep vein thrombosis, coronary artery disease, bleeding disorder, cancer, allergy to vitamin E, significant hepatic and renal impairment, and fever, cold or infection during bleeding day. Subjects with these criteria were excluded: smoker, lactose intolerance, pregnant, lactating, and alcohol drinker. Subjects who were taking vitamin E supplement, medications modulating blood coagulation, hypertension, lipid-lowering and glucose-lowering agents, and corticosteroids were also excluded.

\section{Blood Handling and Sampling}

A day before the study visit, subjects were instructed to avoid consumption of high fat meal, alcohol, and caffeine, strenuous exercise and to fast after $10.00 \mathrm{pm}$ On the study visit day, $2 \mathrm{ml}$ of fasting whole blood sample was collected into VACUETTE® EDTA vacutainer (Greiner BioOne $\mathrm{GmbH}$, Germany) and stored at $15^{\circ} \mathrm{C}$. The samples were analysed within $48 \mathrm{hr}$. Subsequently, $4.5 \mathrm{ml}$ of fasting whole blood was collected into VACUETTE® Z Serum Clot Activator tube (Greiner Bio-One $\mathrm{GmbH}$, Germany). The serum samples were obtained by centrifugation at $3000 \mathrm{rpm}$ for 15 min at $4^{\circ} \mathrm{C}$ and immediately stored at $-80^{\circ} \mathrm{C}$ until analyses. 


\section{Analytical Methods}

Subject compliance was measured by pill counting. The capsules were given to subjects during the first visit of each intervention. On Day 14 of each intervention, the remaining capsules were returned for the pill count. Body weight was measured using TANITA SC-330 body composition analyser (TANITA Corporation, Tokyo, Japan) during each visit without any shoes and accessories.

Haematological parameters were analysed using Sysmex Automated Haematology Analyser XT-4000i (Sysmex Corporation, Kobe, Japan). The parameters measured were red blood cell count (RBC), $\mathrm{Hb}$, haematocrit, RBC indices, mean corpuscular volume $(\mathrm{MCV})$, mean corpuscular haemoglobin $(\mathrm{MCH})$, mean corpuscular haemoglobin concentration (MCHC), platelet count, white blood cell count (WBC), WBC differential count (neutrophil, lymphocyte, monocyte, eosinophil, basophil, and atypical lymphocyte).

Liver function test was analysed using ADVIA ${ }^{\circledR} \quad 2400$ Clinical Chemistry System instrument (Siemens AG, Erlangen, Germany). The measurements included total protein, albumin, globulin, total bilirubin, alkaline phosphatase (ALP), serum aspartate aminotransferase (AST), serum alanine aminotransferase (ALT), and gammaglutamyl transpeptidase (GGT). The reagents used for measurements were obtained from Bayer AG (Germany).

\section{Statistical Analysis}

All data were presented as mean values \pm SD. The distribution of data was examined for normality using D'Agostino \& Pearson normality test in GraphPad Prism (Version5.01; GraphPad Software, Inc., San Diego, California, USA). Logarithmic transformation was performed during the statistical analysis for several parameters including WBC, lymphocyte, monocyte, eosinophil, globulin, total bilirubin, serum glutamic pyruvic transaminase (SGPT), and GGT, but data shown in the results and discussion are the original values. Differences between means were tested with Student's paired t-test for data that were distributed normally. Nonparametric test (Wilcoxon Signed Ranks test) was used for statistical analysis of data that differed from Gaussian distribution. The statistical analysis of Student's paired t-test and Wilcoxon Signed Ranks test was performed using IBM SPSS statistical software (version 20; SPSS, Inc., Chicago, IL, USA).

\section{RESULTS AND DISCUSSION}

A total of 32 subjects (male $n=16$ and female $n=16$ ) were recruited to the study based on the inclusion and exclusion criteria. During intervention, one subject dropped out due to non-compliance as illustrated in the flow chart in Figure 2. The clinical characteristics of the 31 subjects who completed this study are shown in Table 1, with an average age of $37.9 \pm 10.2$ years old. The study was well controlled with more than $98 \%$ compliance as indicated by pill counting. Estimation of energy intake for dinner meal before study visit did not differ significantly $(p>0.05)$ between tocotrienol $(440.29 \pm 126.01 \mathrm{kcal})$ and placebo $(444.60 \pm 121.06 \mathrm{kcal})$ interventions.

Body weight loss, is one of the common measures used in toxicity studies. It is also an important indicator to determine the maximum tolerated dose in animal studies. Oo et al. (1992) showed that administration of T3 dosage up to $2500 \mathrm{mg} \mathrm{kg}^{-1} \mathrm{did}$ not demonstrate any loss of body weight in tested rats. Ima-Nirwana et al. (2011) also found that mice with 14 days of T3 treatment at doses of $200 \mathrm{mg}$ $\mathrm{kg}^{-1}, 500 \mathrm{mg} \mathrm{kg}^{-1}$, and $1000 \mathrm{mg} \mathrm{kg}^{-1}$ showed no effect on the overall growth of mice. In human studies, Mensink et al. (1999), Zaiden et al. (2010), and Yuen et al. (2011) showed that T3 administration up to 160 $\mathrm{mg}$ (42 days), $120 \mathrm{mg}$ (eight weeks), and $300 \mathrm{mg}$ (six months), respectively, had no effect on the body weight compared to placebo control group. In our study, no significant difference in body weight was detected between TRF intervention $(80.0 \pm 16.3 \mathrm{~kg})$ and placebo intervention $(79.9 \pm 16.4 \mathrm{~kg})$. Our results indicated that $\mathrm{T} 3$ administration did not affect the body weight of metabolic syndrome subjects.

The T3 or vitamin E in general is widely claimed to have anti-platelet and anti-coagulation effects on haemostatic system (Dowd and Zheng, 1995). This was shown in an animal study where

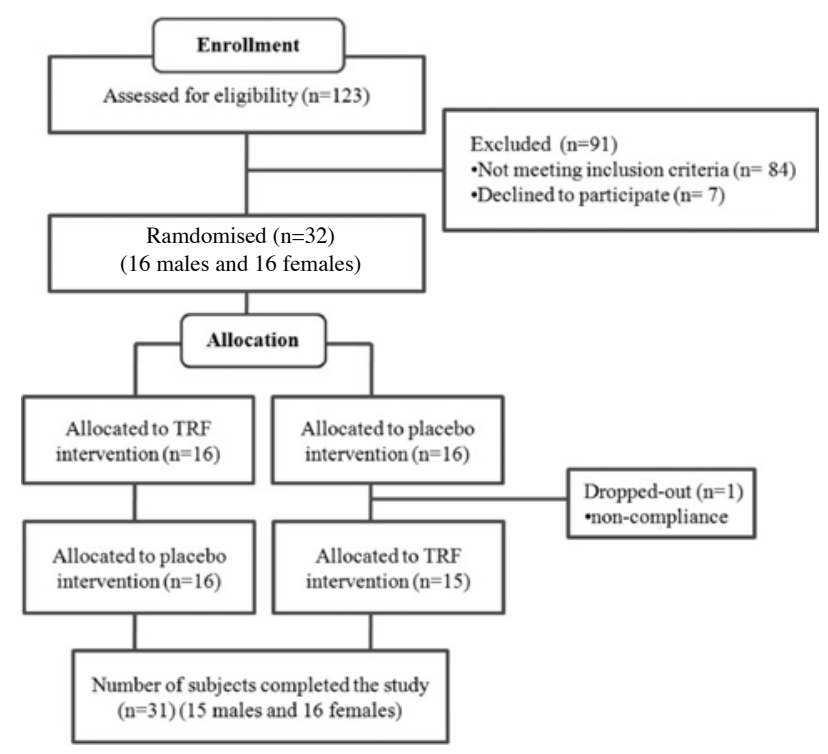

Note: TRF - tocotrienol-rich fraction.

Figure 2. Consort diagram. 
TABLE 1. CHARACTERISTICS OF SUBJECTS

\begin{tabular}{lcc}
\hline & Men $(\mathbf{n}=\mathbf{1 5})$ & Women $(\mathbf{n}=\mathbf{1 6})$ \\
\hline Ethnicity & & \\
$\quad$ Malay & $9(60.0 \%)$ & $14(87.5 \%)$ \\
Chinese & $4(26.7 \%)$ & $0(0.0 \%)$ \\
$\quad$ Indian & $2(13.3 \%)$ & $2(12.5 \%)$ \\
Age (years old) & $34 \pm 8.2$ & $41.6 \pm 10.7$ \\
Weight $(\mathrm{kg})$ & $86.4 \pm 14.6$ & $73.4 \pm 15.3$ \\
BMI (kg m $\left.{ }^{-2}\right)$ & $29.4 \pm 5.3$ & $30.5 \pm 5.4$ \\
Waist circumference (cm) & $100.9 \pm 9.4$ & $96.5 \pm 7.7$ \\
Blood pressure (mm Hg) & & \\
Systolic blood pressure & $133.4 \pm 7.8$ & $133.2 \pm 15.2$ \\
$\quad$ Diastolic blood pressure & $86.4 \pm 7.6$ & $85.2 \pm 9.5$ \\
Serum TAG (mmol litre $\left.{ }^{-1}\right)$ & $2.1 \pm 0.7$ & $1.6 \pm 0.7$ \\
Serum HDL-C (mmol litre $\left.{ }^{-1}\right)$ & $1.0 \pm 0.1$ & $1.2 \pm 0.1$ \\
Fasting glucose (mmol litre $\left.{ }^{-1}\right)$ & $5.1 \pm 0.5$ & $5.1 \pm 0.4$ \\
\hline
\end{tabular}

Note: BMI - body mass index, TAG - triacylglycerol, HDL-C - high density lipoprotein cholesterol.

it was reported that T3 potentially suppressed platelet aggregation with no significant difference on haematocrit and platelet count (Qureshi et al., 2011). In this study, we measured the effect of T3 supplementation on haematological status as shown in Table 2. Post-intervention results showed no significant difference between TRF and placebo interventions on the RBC, platelet count, $\mathrm{Hb}$ level, haematocrit, and RBC indices which included MCV, $\mathrm{MCH}$, and $\mathrm{MCHC}$. Changes in these haematological markers are vital indicators of haemostasis status in the blood circulation. A reduction in RBC count, $\mathrm{Hb}$ level and haematocrit level are associated with blood loss and haemorrhage, while platelets help to inhibit blood loss during vascular injury. An elevated platelet count is associated with an increased risk of thrombosis or inflammation whereas low platelet count prolongs bleeding (Fischbach and Duning III, 2009). In an earlier animal study, administration of $3 \%$ T3 in powdered diet preparation significantly reduced MCV, MCH and platelet count in animal (Nakamura et al., 2001). Later, Tasaki et al. (2008) reported significant reduction of $\mathrm{Hb}$ level, haematocrit, $\mathrm{MCV}$, and $\mathrm{MCH}$ in female rats after 2\% T3 administration in diet. However, the doses of $\mathrm{T} 3$ given for animal were relatively high. In fact, extrapolation of the doses (with an assumption of $60 \mathrm{~kg}$ for human's body weight) showed that the amount of T3 was higher than the upper tolerable limit (1000 $\mathrm{mg}$ per day) of vitamin $\mathrm{E}$ indicated by the Institute of Medicine (IOM) (Institute of Medicine, 2000). Meanwhile, a human study conducted by Nesaretnam et al. (2010) demonstrated that five-year administration of $\mathrm{T} 3$ in breast cancer patients did not change the RBC count, platelet count, $\mathrm{Hb}$ level, and haematocrit. These patients were supplemented with T3 $200 \mathrm{mg}$ together with tamoxifen $20 \mathrm{mg}$ daily. Collectively, our results indicated that the T3 supplementation in humans was not likely to cause bleeding tendency or interfere with the haemostasis status.

In Table 2, we show that $\mathrm{T} 3$ administration had no significant effect on WBC count and WBC differential count, except for lymphocyte and monocyte $(p<$ $0.05)$. However, levels of lymphocyte and monocyte were within the normal range of $20 \%-45 \%$ and $2 \%-10 \%$, respectively. WBC is responsible for body immune system to defend against infection. A decrease in WBC count is found to predispose to infectious diseases, whereas an increase in WBC count is associated with inflammatory and infectious diseases (Fischbach and Duning III, 2009). Present findings showed that $\mathrm{T} 3$ administration had no untoward effect on WBC count and WBC differential counts which is in agreement with the finding by Nesaretnam et al. (2010). Our data suggested that 400 mg T3 supplementation in 14 days did not produce haematotoxicity in metabolic syndrome subjects.

To date, there are limited articles reporting the effect of T3 administration on hepatotoxicity in humans. A previous animal study showed that $2 \%$ of T3 administration in prepared diet significantly increased serum albumin to globulin ratio, SGPT, and ALP levels (Tasaki et al., 2008). Liver function parameters such as total protein, albumin, globulin, total bilirubin levels and albumin to globulin ratio are often related to the functionality of liver, including transportation of organic anions, clearance 
TABLE 2. FASTING HAEMATOLOGICAL PROFILE AFTER TWO WEEKS SUPPLEMENTATION OF TOCOTRIENOL-RICH FRACTION (TRF) AND PLACEBO CAPSULES*

\begin{tabular}{lcc}
\hline & Placebo intervention & TRF intervention \\
\hline RBC $\left(10^{12}\right.$ litre $\left.^{-1}\right)$ & $5.13 \pm 0.76$ & $5.10 \pm 0.78$ \\
$\mathrm{Hb}\left(\mathrm{g} \mathrm{dl}^{-1}\right)$ & $13.83 \pm 1.55$ & $13.65 \pm 1.47$ \\
Haematocrit $(\%)$ & $44.00 \pm 4.78$ & $43.71 \pm 4.34$ \\
RBC indices & & \\
MCV (fl) & $86.65 \pm 6.98$ & $86.68 \pm 7.02$ \\
MCH (pg) & $27.16 \pm 2.70$ & $27.19 \pm 2.87$ \\
MCHC (g dl $\left.{ }^{-1}\right)$ & $31.71 \pm 1.16$ & $31.68 \pm 1.19$ \\
Platelet count $\left(10^{9}\right.$ litre $\left.{ }^{-1}\right)$ & $267.45 \pm 68.72$ & $279.45 \pm 73.86$ \\
WBC $\left(10^{9}\right.$ litre $\left.{ }^{-1}\right)$ & $7.25 \pm 1.95$ & $7.35 \pm 1.59$ \\
WBC differential & & $56.16 \pm 8.58$ \\
Neutrophil $(\%)$ & $53.77 \pm 6.77$ & $37.10 \pm 8.62^{* *}$ \\
Lymphocyte $(\%)$ & $40.03 \pm 6.48^{* *}$ & $3.29 \pm 1.01^{* *}$ \\
Monocyte & $2.77 \pm 1.02^{* *}$ & $3.45 \pm 1.73$ \\
Eosinophil $(\%)$ & $3.42 \pm 1.75$ & $0 \pm 0$ \\
Basophil $(\%)$ & $0 \pm 0$ & \\
Atypical lymphocyte $(\%)$ & $0 \pm 0$ & \\
\hline
\end{tabular}

Note: * $\mathrm{n}=31 ; \mathrm{n}=16$ women; $\mathrm{n}=15$ men.

${ }^{* *} \mathrm{p}<0.05$ between interventions.

$\mathrm{RBC}$ - red blood cell count, $\mathrm{Hb}$ - haemoglobin, $\mathrm{MCV}$ - mean corpuscular volume, $\mathrm{MCH}$ - mean corpuscular haemoglobin, MCHC - mean corpuscular haemoglobin concentration, WBC - white blood cell count.

TRF - tocotrienol-rich fraction.

of endogenous and exogenous substances from blood circulation and the hepatic synthetic function (Khalili et al., 2011). Elevated total serum bilirubin and reduced serum albumin levels would indicate liver dysfunction (Fabry and Narasimhan, 2007). In our results (Table 3), no significant difference was noted between TRF and placebo interventions on total protein, albumin, globulin, total bilirubin levels and the ratio of albumin to globulin. In addition, liver enzymes such as ALP, AST, ALT, and GGT are common serological markers used to detect liver damage. Under normal circumstance, the liver enzymes are situated within the hepatocytes. They will be released into blood circulation when there is a liver injury. Therefore, the serum liver enzyme levels reflect the degree of inflammation in liver (Fabry and Narasimhan, 2007). In our study, ALP, AST, ALT, and GGT levels showed no significant changes after T3 supplementation. Concurring with the human trial by Nesaretnam et al. (2010) which showed that T3 administration at $200 \mathrm{mg}$ per day also did not cause significant change in liver function profile. In animal studies, Ima-Nirwana et al. (2011) found no hepatotoxicity in mice after 14 days and 42 days of T3 treatment at doses of $200 \mathrm{mg}$ $\mathrm{kg}^{-1}, 500 \mathrm{mg} \mathrm{kg}^{-1}$, and $1000 \mathrm{mg} \mathrm{kg}^{-1}$. In addition, T3 was reported to improve liver function by reducing plasma AST and ALT levels induced by high fat diet as shown in a rat study conducted by Weng-Yew et al. (2012). Similar observations were reported when supplementation of T3 at $400 \mathrm{mg}$ per day was shown to delay the progression of end stage liver diseases (Patel et al., 2012). Summarising from the above studies, we believe that supplementation of T3 in humans did not affect liver function nor increase the risk of hepatotoxicity.

In the present study, there was no adverse event or symptom of toxicity reported throughout the study intervention. To date, several acute studies with oral supplementation of palm T3 in a single dose from $200 \mathrm{mg}$ to $1011 \mathrm{mg}$ did not report any acute adverse event (Yap et al., 2001; Yap and Yuen, 2004; Fairus et al., 2006). Also in chronic studies, long-term supplementation of T3 ranging from one month to five years did not report any events of discomfort or toxicities in the subjects investigated (Tomeo et al., 1995; Qureshi et al., 1997; Mensink et al., 1999; Nesaretnam et al., 2010; Zaiden et al., 2010; Mahalingam et al., 2011; Yuen et al., 2011; Heng et al., 2013). Majority of these studies were conducted in subjects with hypercholesterolemia while studies by Rasool et al. (2006; 2008) and Tan et al. (1991) were conducted in healthy human volunteers. Nevertheless, a clinical study by O'Byrne et al. 
TABLE 3. FASTING LIVER FUNCTION PROFILE AFTER TWO WEEKS SUPPLEMENTATION OF TOCOTRIENOL-RICH FRACTION (TRF) AND PLACEBO CAPSULES*

\begin{tabular}{|c|c|c|}
\hline & Placebo intervention & TRF intervention \\
\hline Total protein $\left(\mathrm{g}\right.$ litre $\left.^{-1}\right)$ & $74.32 \pm 3.89$ & $75.03 \pm 4.50$ \\
\hline Albumin (g litre ${ }^{-1}$ ) & $43.68 \pm 2.15$ & $43.61 \pm 2.26$ \\
\hline Globulin ( $\left(\mathrm{g}_{\text {litre }}{ }^{-1}\right)$ & $30.65 \pm 3.84$ & $31.42 \pm 4.15$ \\
\hline Albumin/globulin ratio & $1.44 \pm 0.21$ & $1.42 \pm 0.19$ \\
\hline Total bilirubin $\left(\mu \mathrm{mol}\right.$ litre $\left.^{-1}\right)$ & $12.03 \pm 3.35$ & $11.94 \pm 3.45$ \\
\hline ALP (IU litre $\left.{ }^{-1}\right)$ & $71.58 \pm 19.80$ & $71.77 \pm 16.81$ \\
\hline AST (IU litre ${ }^{-1}$ ) & $27.39 \pm 16.44$ & $25.68 \pm 10.72$ \\
\hline ALT (IU litre $\left.{ }^{-1}\right)$ & $42.23 \pm 33.58$ & $38.26 \pm 24.74$ \\
\hline GGT (IU litre ${ }^{-1}$ ) & $42.71 \pm 39.96$ & $40.06 \pm 25.61$ \\
\hline
\end{tabular}

Note: * $\mathrm{n}=31 ; \mathrm{n}=16$ women; $\mathrm{n}=15$ men.

ALP - alkaline phosphatase; AST - serum aspartate aminotransferase, ALT - serum alanine aminotransferase and GGT - gamma-glutamyl transpeptidase.

TRF - tocotrienol-rich fraction.

(2000) reported the occurrence of side effects in hypercholesterolemic subjects. Among the 51 participants, two subjects had persistent flatulence, one subject had nausea and vomiting, four subjects had transient abdominal distention and gastric upset, and one subject reported hiatal hernia and gastric reflux. It is important to note that the T3 used in the trial was synthetically modified to the form of tocotrienyl acetate, which was different from natural T3 in terms of solubility and physical properties. The European Food Safety Authority (EFSA) published a statement in 2008 to confirm the absence of safety concern with the use of T3 up to $1000 \mathrm{mg}$ per day (EFSA, 2008). Besides, palm TRF was also recognised by the US Food and Drug Administration by obtaining the Generally Recognised as Safe (GRAS) status in 2010 (Schauss et al., 2012). Referring to the recommendation by IOM on vitamin E intake, a tolerable upper intake of up to $1000 \mathrm{mg} \alpha$-T per day is considered safe for adults (Institute of Medicine, 2000). Yet, only $\alpha-T$ is referred as vitamin E, while no recommendation was suggested for the tolerable upper intake level of T3. This indicates a pressing need for reliable data on the tolerance level for T3 as T3 has emerged as the vitamin E beyond tocopherols, exhibiting various unique properties. As such, our present study provides fundamental understanding on the tolerance of T3 supplementation at a daily dose of $400 \mathrm{mg}$. Based on the pharmacokinetic profile of tocotrienols, a twice daily supplementation regimen for more than five days is sufficient to achieve a steady state in healthy subjects (Yap et al., 2001). While there is limited evidence of human study with tocotrienol supplementation in subjects with metabolic syndrome, this study was designed with an intervention period of two weeks as a preliminary investigation. Although the duration of supplementation is relatively short, this study serves as an additional evidence for the establishment of tolerable upper intake levels for T3, which is lacking at present.

\section{CONCLUSION}

This study showed that palm T3 supplementation at $400 \mathrm{mg}$ daily for two weeks did not result in adverse effect in subjects with metabolic syndrome. Haematological status and body weights were not modified after T3 supplementation compared to placebo group. No significant changes in serum markers of liver function and liver enzymes were observed between the T3 and placebo groups. Our results may contribute to the scientific community in the establishment of intake recommendations for T3, particularly the tolerable upper intake levels and recommended daily intake. Nevertheless, more human clinical trials with dose escalation and longer duration might provide insights into the long-term use of T3. Studies with longer duration of supplementation will provide more solid evidence on the safety profile of chronic T3 intake. Besides, detailed toxicology studies are also needed to further confirm our results, as well as to establish the therapeutic window for $\mathrm{T} 3$.

\section{ACKNOWLEDGEMENT}

The authors would like to thank the Director-General of MPOB for supporting the study and permission to publish this article. We would also like to thank the volunteers for their participation in the study as well as laboratory staff in the Nutrition Unit, MPOB for their assistance. A special note of thanks to Hovid Bhd for supplying Tocovid ${ }^{\mathrm{TM}}$ SupraBio $^{\mathrm{TM}} 200 \mathrm{mg}$ and placebo capsules. 


\section{REFERENCES}

BJELAKOVIC, G; NIKOLOVA, D; GLUUD, L L; SIMONETTI, R G and GLUUD, C (2007). Mortality in randomized trials of antioxidant supplements for primary and secondary prevention: systematic review and meta analysis. JAMA Vol. 297 No. 8: 842857.

BJELAKOVIC, G; NIKOLOVA, D; GLUUD, L L; SIMONETTI, R G and GLUUD, C (2012). Antioxidant supplements for prevention of mortality in healthy participants and patients with various diseases. Cochrane Database Syst. Rev. 2012 No. 3 Art No. CD 007176.

BUDIN, S B; OTHMAN, F; LOUIS, S R; BAKAR, M A; DAS, S and MOHAMED, J (2009). The effects of palm oil tocotrienol-rich fraction supplementation on biochemical parameters, oxidative stress and the vascular wall of streptozotoxin-induced diabetic rats. Clinics (Sao Paulo) Vol. 63 No. 3: 235-244.

CLINICAL PRACTICE GUIDELINE (2009). Management of Type 2 Diabetes Mellitus. $4^{\text {th }}$ edition. Ministry of Health, Malaysia.

DOWD, P and ZHENG, Z B (1995). On the mechanism of the anticlotting action of vitamin $E$ quinone. Proc. Natl. Acad. Sci. USA. Vol. 92 No. 18. p. 8171-8175.

EFSA (2008). Opinion on mixed tocopherols, tocotrienol tocopherol and tocotrienols as sources for vitamin $\mathrm{E}$ added as a nutritional substance in food supplements. Scientific opinion of the scientific panel on food additives, flavourings, processing aids and materials in contact with food. (Question No. EFSA Q-2005-146, Q-2005-172, Q-2006-265.) EFSA J. Vol. 640: 1-34.

FABRY, S C and NARASIMHAN, R A (2007). 100 Questions \& Answers about Hepatitis C: A Lahey Clinic Guide. Jones and Bartlett Learning Publishers: Sudbury, Massachusetts.

FAIRUS, S; NOR, $\mathrm{R}$ M; CHENG, $\mathrm{H} \mathrm{M}$ and SUNDRAM, K (2006). Postprandial metabolic fate of tocotrienol-rich vitamin $\mathrm{E}$ differs significantly from that of alpha-tocopherol. Am. J. Clin. Nutr. Vol. 84 No. 4: 835-842.

FISCHBACH, F T and DUNING III, M B (2009). A Manual of Laboratory and Diagnostic Tests. $8^{\text {th }}$ edition. Wolters Kluwer Health/Lippincott Williams \& Wilkins: Philadelphia, USA.

GRUNDY, S M; CLEEMAN, J I; DANIELS, S R; DONATO, K A; ECKEL, R H; FRANKLIN, B A; GORDON, D J; KRAUSS, R M; SAVAGE, P J; SMITH,
S C; SPERTUS, J A and COSTA, F (2005). Diagnosis and management of the metabolic syndrome: an American Heart Association/ National Heart, Lung, and Blood Institute scientific statement. Circulation Vol. 112 No. 17: 2735-2752.

HAFFNER, S M (2006). The metabolic syndrome: inflammation, diabetes mellitus, and cardiovascular disease. Am. J. Cardiol. Vol. 97 No. 2A: 3A-11A.

HENG, E C; KARSANI, S A; ABDUL RAHMAN, M; ABDUL HAMID, N A; HAMID, $Z$ and WAN NGAH, W Z (2013). Supplementation with tocotrienol-rich fraction alters the plasma levels of apolipoprotein A-I precursor, apolipoprotein E precursor, and C-reactive protein precursor from young and old individuals. Eur. J. Nutr. Vol. 52 No. 7: 1-10.

HUANG, P L (2009). A comprehensive definition for metabolic syndrome. Dis. Model Mech. Vol. 2 No. 5-6: 231-237.

IMA-NIRWANA, S and SUHANIZA, S (2004). Effects of tocopherols and tocotrienols on body composition and bone calcium content in adrenalectomized rats replaced with dexamethasone. J. Med. Food Vol. 7 No. 1: 45-51.

IMA-NIRWANA, S; NURSHAZWANI, Y; NAZRUN, A S; NORLIZA, M and NORAZLINA, M (2011). Subacute and subchronic toxicity studies of palm vitamin E in mice. J. Pharmocol. Toxicol. Vol. 6: 166173.

INSTITUTE OF MEDICINE (2000). Dietary Reference Intakes for Vitamin C, Vitamin E, Selenium and Carotenoids. National Academy Press, Washington, DC.

KHALILI, H; DAYEH, B A and FRIEDMAN, L $S$ (2011). Assessment of liver function in clinical practice. Chronic Liver Failure (Gines, P; Kamath, P $\mathrm{S}$ and Arroyo, V eds.). Humana Press, New York, USA. p. 47-76.

KHANNA, S; ROY, S; SLIVKA, A; CRAFT, T K; CHAKI, S; RINK, C; NOTESTINE, M A; DEVRIES, A C; PARINANDI, N L and SEN, C K (2005). Neuroprotective properties of the natural vitamin $\mathrm{E}$ $\alpha$-tocotrienol. Stroke Vol. 36 No. 10: 2258-2264.

KLEIN, E A; THOMPSON, I M; TANGEN, C M; CROWLEY, J J; SCOTT LUCIA, M; GOODMAN, P J; MINASIAN, L M; FORD, L G; PARNES, H L; MICHEAL GAZIANO, J; KARP, D D; LIEBER, M M; WALTHER, P J; KLOTZ, L; PARSONS, J K; CHIN, J L; DARKE, A K; LIPPMAN, S M; GOODMAN, G E; MEYSKENS, F L and BAKER, L H (2011). Vitamin $\mathrm{E}$ and the risk of prostate cancer: the selenium and 
vitamin E cancer prevention trial (SELECT). JAMA Vol. 306 No. 14: 1549-1556.

LONN, E; BOSCH, J; YUSUF, S; SHERIDAN, P; POGUE, J; ARNOLD, J M; ROSS, C; ARNOLD, A; SLEIGHT, P; PROBSTFIELD, J; DAGENAIS, G R and HOPE-TOO TRIAL INVESTIGATORS (2005). Effects of long-term vitamin E supplementation on cardiovascular events and cancer: a randomized controlled trial. JAMA Vol. 293 No. 11: 1338-1347.

MAHALINGAM, D; RADHAKRISHNAN, A K; AMOM, Z; IBRAHIM, N and NESARETNAM, K (2011). Effects of supplementation with tocotrienolrich fraction on immune response to tetanus toxoid immunization in normal healthy volunteers. Eur. J. Clin. Nutr. Vol. 65 No. 1: 63-69.

MILLER, E R; PASTOR-BARRIUSO, R; DALAL, D; RIEMERSMA, R A; APPEL, L J and GUALLAR, E (2005). Meta-analysis: high dosage vitamin E supplementation may increase all-cause mortality. Ann. Intern. Med. Vol. 142 No. 1: 37-46.

MENSINK, R P; HOUWELINGEN, A C; KROMHOUT, D and HORNSTRA, G (1999). A vitamin $\mathrm{E}$ concentrate rich in tocotrienols had no effect on serum lipids, lipoproteins, or platelet function in men with mildly elevated serum lipid concentrations. Am. J. Clin. Nutr. Vol. 69 No. 2: 213219.

NAKAMURA, H; FURUKAWA, F; NISHIKAWA, A; MIYAUCHI, M; SON H Y; IMAZAWA, T and HIROSE, M (2001). Oral toxicity of a tocotrienol preparation in rats. Food Chem. Toxicol. Vol. 39 No. 8: 799-805.

NESARETNAM, K; SELVADURAY, K R; ABDUL RAZAK, G; VEERASENAN, S D and GOMEZ, P A (2010). Effectiveness of tocotrienol-rich fraction combined with tamoxifen in the management of women with early breast cancer: a pilot clinical trial. Breast Cancer Res. Vol. 12 No. 5: R81-R88.

NEWAZ, M A and NAWAL, N N (1999). Effect of gamma-tocotrienol on blood pressure, lipid peroxidation and total antioxidant status in spontaneously hypertensive rats (SHR). Clin. Exp. Hypertens. Vol. 21 No. 8: 1297-1313.

O'BYRNE, D; GRUNDY, S; PACKER, L; DEVARAJ, $S$; BALDENIUS, K; HOPPE, $\mathrm{P} P$; KRAEMER, K; JIALAL, I and TRABER, M G (2000). Studies of LDL oxidation following alpha-, gamma-, or delta-tocotrienyl acetate supplementation of hypercholesterolemic humans. Free Radic. Biol. Med. Vol. 29 No. 9: 834-845.
OO, S L; CHANG, P and CHAN, K E (1992). Toxicological and pharmacological studies on palm vitee. Nutr. Res. Vol. 12 Suppl. 1: S217-S222.

PATEL, V; RINK, C; GORDILLO, G M; KHANNA, S; GNYAWALI, U; ROY, S; SHNEKER, B; GANESH, K; PHILLIPS, G; MORE, J L; SARKAR, A; KIRKPATRICK, R; ELKHAMMAS, E A; KLATTE, E; MILLER, M; FIRSTENBERG, M S; CHIOCCA, E A; NESARETNAM, K and SEN, C K (2012). Oral tocotrienols are transported to human tissues and delay the progression of the model for end-stage liver disease score in patients. J. Nutr. Vol. $142 \mathrm{No}$. 3: 513-519.

PENNOCK, J F; HEMMING, F W and KERR, J D (1964). A reassessment of tocopherol chemistry. Biochem. Biophys. Res. Commun. Vol 17 No. 5: 542-548.

QURESHI, A A; QURESHI, N; WRIGHT, J J; SHEN, Z; KRAMER, G; GAPOR, A; CHONG, Y H; DEWITT, G; ONG, A and PETERSON, D M (1991). Lowering of serum cholesterol in hypercholesterolemic humans by tocotrienols (palmvitee). Am. J. Clin. Nutr. Vol. 53(4 Suppl): 1021S-1026S.

QURESHI, A A; BRADLOW, B A; SALSER, W A and BRACE, L D (1997). Novel tocotrienols of rice bran modulate cardiovascular disease risk parameters of hypercholesterolemic humans. J. Nutr. Biochem. Vol. 8 No. 5: 290-298.

QURESHI, A A; KARPEN, C W; QURESHI, N; PAPASIAN, C J; MORRISON, D C and FOLTS, J D (2011). Tocotrienols-induced inhibition of platelet thrombus formation and platelet aggregation in stenosed canine coronary arteries. Lipids Health Dis. Vol. 10 No. 1: 58-70.

RASOOL, A H; YUEN, K H; YUSOFF, K; WONG, A R and RAHMAN, A R (2006). Dose dependent elevation of plasma tocotrienol levels and its effect on arterial compliance, plasma total antioxidant status, and lipid profile in healthy humans supplemented with tocotrienol rich vitamin E. J. Nutr. Sci. Vitaminol. (Tokyo), Vol. 52 No. 6: 473-478.

RASOOL, A H; RAHMAN, A R; YUEN, $\mathrm{K} \mathrm{H}$ and WONG, A R (2008). Arterial compliance and vitamin E blood levels with a self-emulsifying preparation of tocotrienol rich vitamin E. Arch. Pharm. Res., Vol. 31 No. 9: 1212-1217.

SCHAUSS, A G; ENDRES, J R and CLEWELL, A (2012). Safety of unsaturated vitamin E tocotrienols and their isomers. Tocotrienols: Vitamin $E$ beyond Tocopherols (Tan, B; Watson, R R and Preedy, V R, eds.). AOCS Press: Urbana IL; Taylor \& Francis/ CRC Press: Boca Raton, FL. p. 17-35. 
TAN, D T; KHOR, H T; LOW, W H; ALI, A and GAPOR, A (1991). Effect of a palm-oil-vitamin E concentrate on the serum and lipoprotein lipids in humans. Am. J. Clin. Nutr. Vol. 53 No. 4 Suppl. :1027S-1030S.

TASAKI, M; UMEMURA, T; INOUE, T; OKAMURA, T; KUROIWA, Y; ISHII, Y; MAEDA, M; HIROSE, $M$ and NISHIKAWA, A (2008). Induction of characteristic hepatocyte proliferative lesion with dietary exposure of Wistar Hannover rats to tocotrienol for 1 year. Toxicology Vol. 250 No. 2-3: 143150.

TOMEO, A C; GELLER, M; WATKINS, T R; GAPOR, A and BIERENBAUM, ML (1995). Antioxidant effects of tocotrienols in patients with hyperlipidemia and carotid stenosis. Lipids Vol. 30 No. 12: 1179-1183.

WENG-YEW, W; POUDYAL, H; WARD, L C and BROWN, L (2012). Tocotrienols reverse cardiovascular, metabolic and liver changes in high carbohydrate, high fat diet-fed rats. Nutrients Vol. 4 No. 10: 1527-1541.
YAP, S P; YUEN, K H and WONG J W (2001). Pharmacokinetics and bioavailability of alpha-, gamma- and delta-tocotrienols under different food status. J. Pharm. Pharmacol. Vol.53 No. 1: 67-71.

YAP, S P and YUEN, K H (2004). Influence of lipolysis and droplet size on tocotrienol absorption from selfemulsifying formulations. Int. J. Pharm. Vol. 281 No. 1-2: 67-78.

YUEN, K H; WONG, J W; LIM, A B; NG, B H and CHOY, W P (2011). Effect of mixed-tocotrienols in hypercholesterolemic subjects. Functional Foods in Health and Disease Vol. 3: 106-117.

ZAIDEN, N; YAP, W N; ONG, S; XU, C H; TEO, V H; CHANG, C P; ZHANG, X W; NESARETNAM, K; SHIBA, S and YAP, Y L (2010). Gamma delta tocotrienols reduce hepatic triglyceride synthesis and VLDL secretion. J. Atheroscler. Thromb. Vol.17 No. 10: 1019-1032. 